\title{
Peran Presiden di Era Pemilihan Langsung dalam Mengikis Politik Diametral
}

\author{
Andi Sandi Ant.T.T. ${ }^{1}$
}

Diserahkan: 1 Juli 2021 | Diterima: 12 November 2021 | Diterbitkan: 26 November 2021

\begin{abstract}
Abstrak
Pemilihan presiden secara langsung akan menyebabkan terbentuknya kondisi politik yang diametral di antara pemenang dan pihak yang kalah. Keadaan politik yang diametral itu disebabkan karena penerapan prinsip winner takes all dan separation of powers dalam origin dan survival antara pemegang kekuasaan pemerintahan serta pemegang kekuasaan legislatif. Prinsip-prinsip ini, yang menjadi cacat bawaan dalam sistem presidensial, merupakan penyebab utama terjadinya dead lock dalam pelaksanaan kekuasaan negara. Apakah ada solusi terhadap cacat bawaan tersebut? Guna menemukan solusi itu, fakta dan data pengalaman Indonesia dianalisis dengan menggunakan metode deskriptif kualitatif. Fakta dan data dalam penulisan ini bersumber dari data sekunder yang dipilah menggunakan purposive sampling. Melalui penggunaan kewenangan dan peran yang dimiliki presiden, kondisi politik diametral dapat diminimalisir ataupun dimitigasi. Khususnya, peran presiden sebagai chief of legislator dan arbiter dipastikan dapat mereduksi maupun memitigasi kondisi politik diametral tersebut.
\end{abstract}

Kata Kunci: Kondisi Politik Diametral; Sistem Presidensial; Winner Takes All; Separation of Powers; Chief of Legislator

1 Dosen pada Departemen Hukum Tata Negara, Fakultas Hukum Universitas Gadjah Mada, andi. sandi@ugm.ac.id. 


\section{PENDAHULUAN}

Kondisi politik terbelah antara parlemen dan pemerintah sering terjadi pasca pemilihan langsung presiden. Keadaan ini merupakan konsekuensi logis penerapan winner takes all dalam sistem presidensial. Dalam pengimplementasiannya, winner takes all pasti menghasilkan dua alternatif logis, yaitu pemenang (yang akan menjadi memimpin pemerintahan) dan pihak yang kalah (pihak yang akan menjadi oposisi; tanpa ada kemungkinan terbentuknya pemenang bersama). Di satu sisi, kondisi seperti ini bisa menciptakan pemerintahan yang lebih baik karena pengawasan yang dilakukan oleh parlemen terhadap jalannya pemerintahan dilakukan secara ketat. Pengawasan yang ketat membuat pemerintah bersungguh-sungguh dan berhati-hati dalam melaksanakan kewenangannya serta menggunakan anggaran yang disetujui oleh parlemen dengan lebih efektif dan efisien.

Sebaliknya, dari sudut pandang pesimis, kondisi ini bisa menyebabkan ketidakefektifan atau bahkan sampai kebuntuan dalam proses pelaksanaan pemerintahan. Karena, rencana anggaran yang diajukan oleh pemerintah kepada parlemen dapat saja ditolak. Jika penolakan itu sampai terjadi, maka jalannya pemerintahan akan tersendat. Sebab, tidak tersedia anggaran yang memadai 
guna melaksanakan pelayanan dan pemerintahan. Lihat saja yang terjadi di Amerika Serikat ketika anggaran yang diajukan oleh presiden ditolak oleh the Congress (Weisman, J. dan J.W. Peters, 2013, September 30). Penolakan persetujuan itu mengakibatkan ketersediaan layanan publik menukik tajam karena tidak cukupnya pendanaan untuk membiayai pengeluaran pada sektor publik (Amadeo, K., 2020, 28 Februari dan McCann, E., 2013, 1 Oktober). Jika hal ini terus berlangsung, maka bisa berakhir dengan stuck-nya pemerintahan. Bahkan, tidak menutup kemungkinan terjadi caos (Elgie, 2011).

Kondisiketerbelahaninibisa terusberlangsungselama periode pemerintahan. Kondisi tersebut memperbesar jurang perbedaan, ketegangan dan polarisasi antara pemenang dan loser (Linz, 1990). Perbedaan itu terus dimanfaatkan untuk tetap menggugah semangat para opposant terhadap program-program pemerintah yang berkuasa. Lihat saja, berbagai pandangan yang menyudutkan dari beberapa pihak dengan program pemberantasan corona virus disease 2019 yang dilakukan dalam periode pemerintahan kedua Joko Widodo. Meskipun berbagai data telah disodorkan oleh berbagai kementerian, tetap saja kebijakan dan tindakan yang dilakukan oleh pemerintah dipandang tetap tidak berhasil. Hal ini menunjukkan bahwa Indonesia sedang 
dilanda post truth symptom (Keyes, 2011). Lebih parah lagi, berbagai isu ketidakberhasilan itu dipupuk terusmenerus guna mendorong pemberhentian presiden dalam masa jabatannya.

Ketegangan pun tidak dapat terhindar, antara pihak yang pro terhadap pemerintah dan pihak yang kontra. Pengobaran semangat kontra pemerintah ini dilakukan untuk tetap menggugah para pendukung pihak yang kalah dalam pemilihan umum sebelumnya. Di sisi lain, pihak yang pro terhadap pemerintah juga tidak kalah sengitnya membela kebijakan dan tindakan pemerintah. Jika kondisi ini terus berlangsung, maka polarisasi yang tajam di masyarakat bisa menyebabkan politik diametral. Akhirnya, politik diametral itu bisa membawa dampak keterbelahan kesatuan dan persatuan bangsa.

Keterbelahan juga terjadi di level supra struktur politik, yaitu antarpartai pendukung pemerintah dan partai oposisi. Sebenarnya, keterbelahan antara legislatif dan eksekutif dalam sistem pemerintahan presidensial sudah merupakan ciri bawaan dari sistem presidensial. Sebab, dalam sistem presidensial ditekankan betul garis demarkasi antara pemegang kekuasaan pemerintahan dan kekuasan legislatif. Garis pembatas itu dikenal dengan separation of powers. Di samping itu, desain konstitusional sistem presidensial memang 
hanya mendudukkan kekuasaan legislatif dalam tiga fungsi, yaitu budgeting, legislating, dan supervising. Dengan demikian, kekuasaan legislatif secara sengaja diposisikan sebagai "lawan" dari eksekutif. Artinya, kedua kekuasaan itu memang dirancang untuk saling berlawanan satu dengan lainnya agar satu sama lain bisa saling mengawasi guna mencapai keseimbangan serta terhindar dari absolutisme.

Origin and survival presiden dipisahkan dengan anggota parlemen juga menambah kemungkinan terjadinya kebuntuan dalam pemerintahan (Shugart dan Carey, 1992). Sebab, recruitment pemimpin pemegang kekuasaan pemerintahan dan pemegang kekuasaan parlementer dilakukan secara terpisah. Tidak saling memengaruhi satu dengan yang lainnya. Pemisahan ini membawa konsekuensi pada keberlangsungan menjabat bagi pemimpin kekuasaan pemerintahan maupun anggota parlemen yang tidak saling bergantung satu dengan lainnya. Ketidaksalingbergantungan inilah yang disebut sebagai pemisahan survival (Shugart dan Carey, 1992). Oleh karenanya, dalam sistem presidensial, parlemen tidak dapat memberhentikan presiden dalam masa jabatannya. Begitu pula sebaliknya, presiden tidak dapat membubarkan parlemen. 
Scope of origin dan survival itulah yang dimaknai sebagai separation of powers (Shugart dan Carey, 1992). Jadi dalam sistem presidensial, tidak ada pemisahan kekuasaan secara absolut antara kekuasaan pemerintahan dan parlemen (Shugart dan Carey, 1992). Sebab pada kenyataannya, kedua kekuasaan itu harus saling bekerja sama dalam memutar roda kekuasaan negara. Misalnya, dalam proses pembuatan perjanjian internasional maupun peryataaan perang kepada negara lain atau organisasi tertentu (U.S.Const. Art.II, §2 dan UUD NRI, Pasal 11). Jika dilakukan pemisahan secara tegas, tidak mungkin terjadi kerja sama keduanya dalam melaksanakan kewenangan konstitusional tersebut. Di samping itu, separation of powers bukan saja menjadi monopoli sistem presidensial. Separation of powers pun terdapat dalam sistem pemerintahan parlementer (Verney, 1959). Dalam sistem parlementer, prinsip pemisahan kekuasaan dapat dilihat pada pemisahan secara tegas antara kekuasaan simbolik (nominal power)-yang diatribusikan kepada kepala negara-dan kekuasaan pemerintahan (real power) yang diemban oleh perdana menteri dan kabinet pemerintahan (Strong, 1963).

Keterpisahan dan ketidaksalingbergantungan ini menambah subur rivalitas antara pemegang kekuasaan 
pemerintahan dan parlemen. Apalagi dalam sistem presidensial, tingkat kedisiplinan anggota legislatif pada partainya juga rendah (Cheibub, 2007). Rendahnya kepatuhan anggota legislatif pada partainya disebabkan karena absennya insentif bagi anggota parlemen yang patuh kepada partainya (Cheibub, 2007). Kepatuhan yang dimaksudkan dalam konteks ini adalah kepatuhan para anggota partai untuk mendukung pemerintahan yang diusung oleh partainya. Ketiadaan insentif tersebut dapat menyebabkan anggota parlemen lebih mengutamakan keberlanjutan posisinya di parlemen daripada memenuhi kebutuhan partai politiknya.

Dengan demikian, winner takes all, origin, dan survival, serta separation of powers merupakan kombinasi premis yang akan menyebabkan terjadinya dead lock atau kebuntuan dalam sistem presidensial. Kombinasi inilah yang disebut oleh Juan Jose Linz sebagai "cacat bawaan" yang terdapat dalam sistem presidensial. Karena merupakan defect, semua sistem presidensial pasti melahirkan dan melanggengkan rivalitas antara kubu pemenang dan kalah. Bahkan Lins sampai mengatakan, "... no democratic principle exists to resolve disputes between the executive and the legislature about which of the two actually represents the will of the people." (Linz, 1990). 
Apakah kondisi politik diametral di masyarakat serta dalam hubungan eksekutif dan legislatif tidak bisa diatasi atau setidaknya diminimalisir? Permasalahan inilah yang menjadi tujuan utama artikel ini. Artikel ini berusaha menawarkan bagaimana mengatasi tradisi adversarial di masyarakat sebagai imbas kompetisi pemilihan presiden. Selain itu, tulisan ini pun ingin membantah hipotesis Juan Jose Linz yang menganggap tidak ada jalan keluar untuk mengatasi keterbelahan di masyarakat dan supra struktur politik yang terjadi dalam sistem presidensial. Guna mencari dan menjelaskan solusi itu, narasi, fakta, data, dan analisis pun difokuskan pada pengalaman Indonesia dan Amerika Serikat dalam menyelesaikan rivalitas tersebut. Data dan fakta dalam penulisan ini bersumber pada data sekunder yang dipilah menggunakan purposive/judgmental sampling (Soekanto, 1986). Data dan fakta yang dikumpulkan kemudian dipilah berdasarkan kriteria tertentu. Kriteria itu meliputi data dan fakta yang berkaitan dengan karakteristik sistem presidensial, kewenangan dan fungsi presiden, serta hubungan presiden dan parlemen. Selanjutnya, data dan fakta itu dianalisis dengan menggunakan metode deskriptif kualitatif melalui statutory approach, historical approach, dan comparative approach (McConville dan Chui, 2007). 
Indonesia dan Amerika Serikat dijadikan model dalam pendekatan perbandingannya. Walaupun sampai saat ini, sistem pemerintahan Indonesia belum mempunyai kejelasan apakah dikategorikan sistem parlementer, presidensial, atau hybrid. Guna memastikan sistem pemerintahan yang diberlakukan di Indonesia pasca perubahan Undang Undang Dasar 1945 (UUD 1945), artikel ini berusaha memastikan sistem presidensial sebagai sistem yang diterapkan di Indonesia terlebih dahulu. Kepastian itu diperlukan untuk menghilangkan keraguan dari sisi normatif maupun teoretik mengenai sistem pemerintahan Indonesia.

Dengan mendasari pada kesimpulan sistem pemerintahan yang diterapkan di Indonesia, tulisan ini berusaha mengoreksi kesimpulan Juan Jose Linz mengenai ketiadaan jalan keluar atas defect yang terkandung dalam sistem pemerintahan presidensial. Koreksi atas kesimpulan Linz itu dimaksudkan untuk mengatakan bahwa sistem pemerintahan presidensial terus berevolusi sesuai dengan perkembangan zaman dan sosial guna menemukan jalan keluarnya sendiri atas segala kekurangan yang dimilikinya. Evolusi itu terjadi karena adanya variasi features baru dalam sistem presidensial yang digagas dan diterapkan dalam konstitusi-konstitusi negara yang menerapkan. Dengan 
demikian, sistem presidensial bukanlah sebuah sistem yang lebih buruk dari sistem parlementer ataupun hybrid, sebagaimana dikumandangkan oleh Juan Jose Linz dan para pendukungnya.

\section{SISTEM PEMERINTAHAN INDONESIA: PRESIDENSIAL, PARLEMENTER, ATAU SEMI PRESIDENSIAL?}

Pasca dilakukannya amandemen terhadap UUD 1945, sistem pemerintahan Indonesia cenderung mengarah pada sistem presidensial. Penguatan atas karakteristik sistem presidensial merupakan salah satu arah perubahan UUD 1945 (Majelis Permusyawaratan Rakyat, 2017). Hasilnya, berbagai ciri sistem presidensial pun dapat ditemukan dalam ketentuan Undang Undang Dasar Negara Republik Indonesia Tahun 1945 (UUD NRI Tahun 1945). Ciri tersebut meliputi presiden dan wakil presiden dipilih secara langsung (UUD NRI, Pasal 6A ayat (1)), presiden mempunyai masa jabatan tertentu (UUD NRI, Pasal 7), presiden mengangkat dan memberhentikan menteri (UUD NRI, Pasal 17 ayat (2)), presiden tidak dapat membubarkan parlemen (UUD NRI, Pasal 7C), serta presiden merupakan kepala negara (UUD NRI, Pasal 10-15) dan kepala pemerintahan (UUD NRI, Pasal 4 ayat (1)). Dari berbagai ketentuan 
itu, dapat disimpulkan secara mudah bahwa sistem pemerintahan yang diterapkan di Indonesia merupakan sistem pemerintahan presidensial.

Mohammad Fajrul Falaakh menyimpulkan bahwa sistem pemerintahan Indonesia tidak hanya memenuhi ciri-ciri sistem pemerintahan presidensial namun juga "mengandung" ciri sistem pemerintahan parlementer. Ciri sistem parlementer itu terlihat pada fusion of executive and legislative power dalam pembentukan Undang-undang, eksistensi koalisi partai politik pendukung pemerintahan dan monopoli partai politik dalam pencalonan presiden dan wakil presiden (Komisi Hukum Nasional, 2014). Akibatnya, ia menyimpulkan bahwa sistem pemerintahan Indonesia adalah sistem parlementer lewat pintu belakang (Falaakh, 2003). Kesimpulan itu ditarik dari berbagai ciri presidensial yang tersurat dengan jelas dalam UUD NRI Tahun 1945 meski terselip juga ciri parlementer di antara dominasi karakteristik presidensial, yaitu adanya persetujuan bersama antara Dewan Perwakilan Rakyat dan Presiden dalam pembentukan Undang-undang (UUD NRI, Pasal 20 ayat (2)).

Keberadaan karakteristik presidensial dan parlementer dalam sistem pemerintahan Indonesia, kemudian menyebabkan tidak sedikit yang berpendapat 
bahwa sistem pemerintahan Indonesia merupakan sistem semi-presidensial, sistem campuran, atau sistem MPR (Kelompok Kerja Forum Rektor). Dikatakan semipresidensial karena karakteristik presidensial lebih dominan jika dibandingkan dengan ciri parlementer. Ide semi-presidensial pertama kali diusulkan oleh Maurice Duverger ketika mengambarkan sistem pemerintahan Perancis berdasarkan Konstitusi Republik Ke-V (Kaminsky, 1997). Sistem ini mengakui dan menerapkan eksistensi dual executive, yaitu terdapat presiden yang mempunyai real power, di samping perdana menteri yang juga memiliki real power on daily basis.

Realitas pembauran berbagai karakteristik sistem pemerintahan itu perlu diperjelas dengan mendasarkan pada ciri utama setiap sistem pemerintahan yang ada. Sebelum menguraikan karakter presidensial, parlementer, maupun campuran, perlu ditegaskan terlebih dahulu mengenai makna atau batasan dari sistem pemerintahan, khususnya dalam sistem politik yang demokratik. Sistem pemerintahan adalah metode atau cara penyelenggaraan kekuasaan pemerintahan negara (eksekutif) guna mencapai tujuan bernegara. Makna ini disarikan dari pendapat yang disampaikan oleh beberapa pakar, yaitu Pamudji (Pamudji, 1994), I Made Pasek Diantha (Diantha,1990), Ismail Suny 
(Suny,1987), Mahfud M.D. (Mahfud, 2001), Sri Soemantri (Soemantri, 1992), Jimly Asshiddiqie (Asshiddiqie, 2007), dan Saldi Isra (Isra, 2019). Oleh karenanya, epicentrum sistem pemerintahan terletak pada kekuasaan eksekutif sehingga pembahasan mengenai parlementer, presidensial, atau hybrid, lebih ditekankan pada siapa yang ditugaskan melaksanakan kekuasaan pemerintahan.

Parameter utama sistem parlementer terletak pada pertanggungjawaban pemegang kekuasaan pemerintahan kepada parlemen. Kekuasaan eksekutif dalam sistem ini diatribusikan pada kabinet menteri yang dipimpin oleh perdana menteri. Konsekuensiya, jika dalam sebuah pemerintahan, pemegang pemerintahan bertanggung jawab kepada parlemen, maka sistem itu dikategorikan sebagai sistem parlementer. Titik tekan pada pertanggungjawaban kabinet menteri pada parlemen sebagai ciri khas sistem parlementer digagas oleh C.F. Strong (Strong, 1963). Ide ini kemudian juga disetujui oleh Juan Jose Linz (Linz, 1990), Giovanni Sartori (Sartori,1994), Gonzalo Villalta Puig (Puig, 2002), Matthew Søberg Shugart (Shugart, 2005), Jose Antonio Cheibub (Cheibub, 2007), Miriam Budiardjo (Budiardjo, 2008), Adam Przeworski, Tamar Asadurian, dan Anjali Thomas Bohlken (Przeworski et.al, 2012), serta Marcos 
Yamada Nakaguma (Nakaguma, 2015). Kesemua ahli ini berpendapat bahwa ciri pembeda utama dari sistem parlementer adalah pertanggungjawaban kabinet menteri kepada parlemen. Oleh karenanya, eksistensi kekuasaan eksekutif bergantung pada dukungan atau kepercayaan dari kekuasaan legislatif. Jadi, tidak mengherankan jika dalam sistem parlementer terdapat kecenderungan untuk bekerja sama atau berkoalisi. Koalisi dibutuhkan untuk mempertahankan eksistensi kabinet pemerintahan.

Selain pertanggungjawaban pemegang kekuasaan eksekutif kepada parlemen, sebenarnya masih terdapat berbagai macam ciri khas dari sistem parlementer. Misalnya, pemisahan antara pemegang kekuasaan pemerintahan dan kekuasaan nominal, kabinet pemerintahan dapat menjabat sebagai anggota parlemen, pembubaran parlemen atas usul perdana menteri, dan pembubaran kabinet pemerintahan jika mendapat mosi tidak percaya dari parlemen. Kekhasan ini sudah banyak dirinci dan dijelaskan oleh para pakar sejak lama. Mulai dari Douglas V. Verney (Verney, 1959), Arend Lijphart (Lijphart, 1984), Allan R. Ball (Ball, 1988), Gregory S. Mahler (Mahler, 2000), Moh.Mahfud M.D. (Mahfud M.D., 2001), Rob Hague dan Martin Harrop (Hague dan 
Harrop, 2004), Jimly Asshiddiqie (Asshiddiqie, 2007), serta Saldi Isra (Isra, 2019).

Apabila didasarkan pada kriteria utama yang dipaparkan di atas, maka sistem pemerintahan Indonesia berdasarkan UUD Negara RI Tahun 1945 tidak dapat dikategorikan ke dalam sistem parlementer. Dalam konteks Indonesia, para menteri berada di bawah dan bertanggung jawab kepada presiden. Selain itu, presiden ataupun para menteri tidak bergantung eksistensinya pada kepercayaan dari parlemen, tetapi presiden mempunyai masa jabatan tertentu dan bertanggung jawab langsung kepada voters. Ditambah lagi, adanya larangan bagi presiden untuk membekukan atau membubarkan parlemen. Padahal, kewenangan presiden atau kepala negara untuk membubarkan parlemen merupakan salah satu kewenangan spesifik yang diberikan oleh konstitusi kepada presiden atau kepala negara dalam sistem parlementer, sebagaimana disebutkan oleh Douglas V. Verney (Verney, 1959).

Presiden dalam sistem parlementer diposisikan sebagai pemegang nominal power. Ia hanya mempunyai peran sebagai simbol dari negara. Tidak mengherankan jika kepala negara dalam sistem parlementer cenderung tidak sepopuler perdana menteri. Popularitas presiden dalam sistem presidensial sangat jauh berbeda dengan 
counterpart-nya di sistem parlementer. Mengapa presiden sangat popular? Karena, presiden dalam sistem presidensial merupakan centerpiece of presidential branch (Polsby, 2011). Selain sebagai pusat kekuasaan eksekutif, presiden juga merupakan pengendali utama kekuasaan pemerintahan negara. Sebab, para menteri maupun lembaga pemerintah lainnya berada di bawah tanggung jawab presiden. Oleh karenanya, presiden jauh lebih popular dalam sistem presidensial karena merupakan pusat dari kekuasaan eksekutif yang ditugaskan untuk melaksanakan pemerintahan negara.

Para ahli juga telah menyodorkan berbagai karakteristik dari sistem presidensial. Evolusi jumlah ciri presidensial pun seturut dengan jumlah ciri parlementer, yaitu semakin lama, semakin minim jumlahnya. Ini terjadi karena begitu banyaknya variasi dari sistem presidensial yang diberlakukan di berbagai negara. Evolusi ciri sistem presidensial dimulai dari Douglas V. Verney (Verney, 1959) kemudian dilanjutkan oleh C.F. Stong (Strong, 1963), Arend Lijphart (Lijphart, 1984), Juan Jose Linz (Linz, 1990), Matthew Soberg Shugart dan John M. Carey (Shugart dan Carey, 1992), Soemantri (Seomantri, 1992), Giovanni Sartori (Sartori, 1994), Scott Mainwaring dan Matthew S. Shugart (Mainwaring dan Shugart, 1997), Elijah Ben-Zion 
Kaminsky (Kaminsky, 1997), Allan R. Ball (Ball, 1998), Sri Bagir Manan (Manan, 1999), Gregory S. Mahler (Mahler, 2000), Moh. Mahfud M.D. (Mahfud M.D., 2001), Jimly Asshiddiqie (Asshiddiqie, 2007), Miriam Budiardjo (Budiardjo, 2008), dan terakhir Saldi Isra (Isra, 2019).

Jumlah karakteristik yang disampaikan oleh para ahli mulai menurun dari sembilan dan terus menurun sampai hanya dua ciri yang diajukan oleh Mainwaring dan Shugart. Bahkan, terdapat juga ciri yang sangat minimalis yang dipelopori oleh C.F. Strong. Ia hanya menitikberatkan pada pertanggungjawaban pemimpin kekuasaan eksekutif. Apakah bertanggung jawab kepada parlemen ataukah tidak (Strong, 1963). Pola pertanggungjawaban dan eksistensi keberlanjutan pemimpin kekuasaan eksekutif juga menjadi fokus ciri yang diajukan oleh I Made Pasek Diantha (Diantha, 1990), Hans Keman (Keman, 2002), Gonzalo Villalta Puig (Puig, 2002), Jose Antonio Cheibub (Cheibub, 2007), Jean Blondel (Blondel, 2015), dan Marcos Yamada Nakaguma (Nakaguma, 2005). Artinya, sistem presidensial mempunyai karakteristik pokok bahwa pemimpin kekuasaan pemerintahan tidak bertanggung jawab kepada parlemen karena yang bersangkutan mempunyai masa jabatan tertentu. Dengan ciri khas 
tersebut, sistem pemerintahan presidensial cenderung melahirkan tradisi separation dalam pelaksanaannya. Jadi, tidak mengherankan jika terjadi politik diametral dalam suprastruktur maupun infrastruktur politiknya.

Melihat ciri yang diajukan oleh para ahli pada sistem presidensial, Indonesia dikategorikan dalam sistem presidensial. Kesimpulan ini didasarkan pada ketentuan konstitusional yang menyebutkan bahwa pemegang kekuasaan pemerintahan negara dipilih secara langsung dan tidak ada kewajiban untuk memberikan pertanggungjawaban performance pemerintahannya kepada parlemen atau pemegang kekuasaan legislatif. Lalu, bagaimana dengan ketentuan joint approval terhadap pembentukan Undang-undang? Sebab, ciri ini tidak disebutkan sebagai salah satu ciri dari sistem presidensial. Apakah kemudian dengan keberadaan ciri ini, sistem pemerintahan Indonesia dikategorikan sebagai sistem pemerintahan hybrid?

Sistem pemerintahan campuran atau hybrid, pertama kali diinisiasi oleh Maurice Duverger. Menurutnya, sistem tersebut bercirikan sebagai berikut (Duverger, 1980).

1. The presidential of the republic is elected by universal suffrage 
2. He possesses quite considerable power

3. He has opposite him, however, a prime minister and ministers who possess executive and governmental power and can stay in the office if the parliament does not show its opposite to them

Kemudian, ciri ini berkembang seturut dengan variasi sistem campuran. Disebut sistem pemerintahan campuran karena sistem ini mengabungkan ciri dari sistem presidensial dan parlementer. Perkembangan sistem ini mengakibatkan pandangan mengenai cirinya pun sangat bervariasi.

Karakateristik yang diajukan oleh Juan Jose Linz (Linz, 1994), Steven D. Roper (Roper, 2002), Rob Hague dan Martin Harrop (Hague dan Harrop, 2004), Matthew Søberg Shugart (Shugart, 2005), Jimly Asshiddiqie (Asshiddiqie, 2007), Robert Elgie (Elgie, 2004), Cindy Skach (Skach, 2007), Giovanni Sartori (Sartori, 1994), Saldi Isra (Isra, 2019), dan Rui Graça Feijó (Feijó, 2021) menunjukkan hal yang sama dengan yang disampaikan oleh Duverger. Artinya, suatu negara dapat dikelompokkan sebagai negara yang menerapkan sistem campuran apabila dalam negara itu terdapat presiden yang dipilih langsung, perdana menteri yang 
memimpin pemerintahan sehari-hari, dan perdana menteri bergantung eksistensinya pada kepercayaan parlemen. Melihat ciri pokok yang disampaikan oleh para ahli ini, Indonesia tidak dapat dikategorikan masuk dalam sistem campurna karena tidak ada jabatan perdana menteri. Apalagi perdana menteri yang bergantung keberadaannya pada parlemen.

Dengan mendasari pada karakteristik sistem pemerintahan yang telah diuraikan, maka dapat dipastikan bahwa Indonesia menerapkan sistem presidensial. Lalu, bagaimana dengan keberadaan joint approval pada pembentukan Undang-undang di Indonesia? Mengenai hal ini, Shugart dan Carey telah menyebutkan bahwa dalam suatu sistem presidensial tidak ada separation of powers yang absolut. Di samping itu, presiden pun mempunyai kekuasaan legislatif (Shugart dan Carey, 1992). Besar, luas, atau tidaknya kewenangan legislatif presiden tidak bisa ditentukan secara pasti karena sangat bervariasinya kewenangan legislatifyang diatribusikan kepada pemegang kekuasaan eksekutif (Shugart dan Carey, 1992). Mulai dari yang hanya berhak mengusulkan rancangan Undang-undang sampai dengan menetapkan Undang-undang dalam keadaan darurat (Shugart dan Carey, 1992). Dengan demikian, keberadaan joint approval bukan menjadi 
halangan sistem pemerintahan Indonesia dikategorikan sebagai sistem presidensial.

Features joint approval dalam sistem presidensial Indonesia memang didesain untuk mengatasi ketidakstabilan dan dead lockyang merupakan defect dari sistem parlementer dan presidensial. Ketidakstabilan merupakan cacat bawaan dari sistem parlementer karena eksistensi kekuasaan eksekutif sangat bergantung pada kepercayaan parlemen. Karenanya, pergantian pemegang kekuasaan eksekutif menjadi sering terjadi dan berujung pada gangguan stabilitas politik. Bahkan, untuk melegitimasi pergantian kekuasaan eksekutif pun, tidak jarang diperlukan pemilihan umum. Pelaksanaan pemilihan umum itu tidak hanya memakan biaya yang besar dan memakan waktu, tetapi energi yang dikeluarkan pun semakin banyak. Bahkan, fokus terhadap proses pembangunan juga dapat terabaikan. Realitas ketidakstabilan dan seringnya terjadi pergantian pemegang kekuasaan eksekutif dapat terlihat jelas ketika Indonesia menerapkan sistem parlementer pada saat berlakunya Konstitusi Republik Indonesia Serikat dan Undang-Undang Dasar Sementara 1950.

Pengadopsian sistem presidensial secara strict pun juga bisa bermasalah. Permasalahan ini disebabkan oleh pemahaman bahwa harus ada pemisahan yang tegas di 
antara para pemegang kekuasaan negara. Keterpisahan itu bisa menyebabkan terjadinya absolutisme relatif dan dead lock. Guna menghindarinya, para desainer sistem pemerintahan Indonesia memasukkan semacam cara untuk "memaksa" para pemegang kekuasaan negara bekerja sama dalam melaksanakan kewenangan yang diatribusikan padanya. Pola kerja sama inilah yang kemudian dikenal dengan checks and balances. Ketika proses saling mengawasi dan mengimbangi dimaksudkan untuk mengatasi absolutisme relatif, para pengagas Indonesia menemukan cara baru untuk mengimplementasikannya. Cara itu dilakukan dengan mencampurkan para pemegang kekuasaan negara dalam pelaksanaan kewenangan atau kekuasaan. Pola ini merupakan pola yang dilahirkan oleh para founding fathers Indonesia.

Mencampurkan para pemegang kekuasaan negara itu dapat dilihat pada pola keanggotaan Majelis Permusyawaratan Rakyat (MPR) atau Majelis Kehormatan Kehakiman (MKH). Dalam MPR, terdapat anggota DPR dan DPD sedangkan dalam $\mathrm{MKH}$ terdapat hakim agung dan komisioner Komisi Yudisial. Pembauran keanggotaan ini tidak hanya dimaksudkan untuk menghasilkan keputusan yang netral, tetapi juga untuk menghindari kebuntuan. Pola inilah yang juga 
diterapkan untuk mengatasi dead lock yang terkandung dalam sistem presidensial. Jadi, tidak mengherankan jika tradisi inijuga diterapkan pada mekanisme pembentukan Undang-undang. Dalam proses itu, dominasi dari salah satu pemegang kekuasaan negara dapat dinetralisir dengan memasukkan pemegang kekuasaan negara lainnya. Oleh sebab itu, joint approval yang terdapat dalam sistem presidensial Indonesia tidak berarti bahwa sistem pemerintahan yang diterapkan adalah sistem hybrid. Melainkan, sistem presidensial dengan mekanime pembauran pemegang kekuasaan negara dalam pelaksanaan kewenangan konstitusionalnya.

Dengan dikategorikan sebagai negara yang menerapkan sistem presidensial, Indonesia sangat dimungkinkan bisa mengalami kondisi politik yang diametral sebagai dampak prinsip winner takes all dan separation of powers. Bagaimana politik diametral ini dimitigasi atau diminimalir? Apakah tidak ada jalan keluar untuk menyelesaikannya sebagaimana pandangan yang disampaikan oleh Juan Jose Linz? 


\section{KEWENANGAN DAN PERAN PRESIDEN: TERBATAS PADA KEPALA PEMERINTAHAN DAN KEPALA NEGARA?}

Kekuasaan pemerintahan diatribusikan kepada presiden sebagaimana ditentukan dalam the Article II section 1 paragraph (1) of the U.S. Constitution. Dengan kedudukannya sebagai pemegang kekuasaan eksekutif, Presiden Amerika Serikat berwenang mengangkat dan memberhentikan para menteri dan para pegawai yang berada dalam lingkup kekuasaan eksekutif. Di samping itu, ia juga mempunyai kekuasaan sebagai representasi Amerika Serikat ketika berhadapan dengan negara lain. Kedudukan inilah yang disebut kekuasaan nominal atau kekuasaan sebagai kepala negara. Jadi, tidak mengherankan ketika Presiden Amerika Serikat juga mempunyai posisi sebagai "The Chief of Armed Forces" yang ditentukan dalam the Article II Section 2 paragraph (1) of the U.S. Constitution.

Kewenangan-kewenangan Presiden Amerika Serikat itu juga dimiliki oleh Presiden Indonesia sebagaimana diatur dalam Pasal 4 ayat (1), Pasal 10, Pasal 11, dan Pasal 17 UUD NRI Tahun 1945. Kewenangan-kewenangan inilah yang disebut nominal power dan real power (Strong, 1963). Dengan menyatunya kedua kekuasaan itu pada satu tangan, tidak mengherankan jika presiden 
dijuluki sebagai center of the executive branch (Polsby, 2011). Sebab, kekuasaan pemerintahan harus berada dalam kendalinya. Pemusatan kekuasaan dalam tangan presiden itu dilandasi unitary executive theory yang digagas oleh para founding fathers Amerika Serikat. Dalam teori ini, disebutkan bahwa presiden harus memiliki kontrol tunggal terhadap kekuasaan eksekutif (Calabresi dan Rhodes, 1992). Artinya, kekuasaan eksekutif tidak terbagi dan dikontrol sepenuhnya oleh presiden. Dengan kata lain, seluruh bagian dari kekuasaan negara yang melaksanakan fungsi eksekutif harus berada di bawah dan dikontrol oleh presiden.

Teori inilah yang menjadi fokus utama para kritikus yang tidak menyukai besarnya kekuasaan yang dimiliki oleh presiden. Guna mereduksi kekuasaan presiden, para kritikus itu kemudian mengusulkan ide untuk melahirkan lembaga yang diberi trade mark "independent" dalam sistem pemerintahan Amerika Serikat. Eksistensi lembaga independen di Amerika Serikat dimaksudkan sebagai bentuk reduksi kekuasaan yang sangat besar yang dipegang oleh presiden. Akibatnya, the Congress juga dapat ikut campur tangan dalam proses pelaksanaan kekuasaan pemerintahan melalui kontrol yang mereka lakukan melalui peraturan (act) dan pengesahan anggarannya (Calabresi dan 
Rhodes, 1992). Namun dalam konteks Indonesia, lembaga-lembaga independen yang ada pada hari ini tidak dibentuk untuk mereduksi kewenangan presiden sebagaimana ditentukan dalam UUD NRI Tahun 1945. Tetapi, lembaga-lembaga semacam itu dibentuk karena ketidakpercayaan publik pada kekuasaan formal yang ada pada saat itu (Cornelis, 2006). Dengan label independent, lembaga-lembaga negara sampiran (Lay, 2006) itu kemudian dapat bertindak lebih leluasa di luar kontrol eksekutif.

Pola pengambilalihan kekuasaan eksekutif yang dilakukan oleh the Congress menggambarkan bahwa cara perebutan kekuasaan tetap dilakukan oleh pihak yang kalah dalam kontestasi pemilihan umum presiden. Dendam atas kekalahan masih terus dihayati oleh pihak yang kalah sehingga tetap selalu mencoba untuk menguasai pemerintahan. Preservasi kekalahan dalam kompetisi presidensial terus digelorakan sampai kekuasaan pemerintahan berpindah kepada pihak yang kalah. Realitas ini jelas menunjukkan bahwa penerapan winner takes all mengakibatkan dendam kesumat yang tidak berkesudahan.

Oleh karena itu, dendam kesumat tersebut harus dapat dimitigasi ataupun diminimalisir. Tanpa diminimalisir, kondisi politik tidak akan pernah kondusif 
untuk melaksanakan pembangunan. Semua energi akan dihabiskan untuk melancarkan pembalasan kepada pihak yang memenangi pemilihan presiden. Kekacauan di Capitol Hill pada Januari 2021 merupakan contoh termutakhir bagaimana rivalitas antar para pendukung calon presiden dapat mengakibatkan tereduksinya prinsip-prinsip demokrasi yang beradab. Karenanya, harus ada pihak yang menyelesaikan dendam kesumat itu melalui cara-cara yang demokratis agar energi yang tersedia dapat digunakan untuk mewujudkan kesejahteraan dan ketenteraman.

Salah satu pihak yang dapat melakukan hal tersebut adalah sosok yang dapat diterima oleh semua pihak. Sosok ini harus mampu meredam ataupun meminta perselisihan yang terus terjadi untuk segera disudahi. Usaha untuk meredam itu pun didengarkan dan dipatuhi oleh semua pihak yang bertikai. Kesemua kriteria ini dapat ditemukan dalam presiden. Sebab menurut Clinton Rositter, Presiden Amerika Serikat mempunyai 10 peran, yaitu chief of state, chief of executive, commander-in-chief, chief of diplomat, chief of legislator, chief of party, voice of people, protector of peace, manager of prosperity, dan world leader (Rossiter, 1963). 
Dalam perannya sebagai protector of peace, presiden dapat menyelesaikan segala hal yang mengganggu ataupun menghambat kehidupan masyarakat (Rossiter, 1963). Mulai dari hambatan yang disebabkan oleh alam sampai dengan ancaman kekerasan yang dilakukan oleh manusia. Hal ini dikarenakan presiden mempunyai kewenangan untuk mengerahkan segala macam bala bantuan. Baik itu yang berupa dana, keahlian, personil maupun peralatan guna mengatasi gangguan atau bencana yang sedang melanda negaranya. Implementasi ini juga terlihat dengan jelas ketika Joko Widodo memerintahkan untuk melakukan refocusing anggaran pemerintahan agar anggaran tersebut dapat digunakan untuk mengatasi wabah corona virus disease 2019 (Rahayu Puspasari, 2020). Semua kementerian dan lembaga diminta untuk melakukan hal tersebut. Di sisi yang lain, pengarahan personil maupun peralatan kepolisian dan tentara juga diperintahkan oleh presiden guna menyediakan fasilitas kesehatan bagi masyarakat yang terdampak virus tersebut (Binti Sholikah dan Hiru Muhammad, 2021). Kedua kebijakan dan tindakan itu memastikan bahwa Presiden Indonesia juga mempunyai peran sebagai protector of peace.

Meskipun kebijakan-kebijakan tersebut di atas diambil untuk mengatasi keadaan darurat, posisi 
sebagai protector of peace juga dapat digunakan dan dimanfaatkan untuk mencapai solusi atas politik diametral. Sebagai presiden, posisinya merupakan milik dari semua golongan, bukan lagi hanya menjadi milik partai atau koalisi partai pendukungnya. Jika seorang presiden sadar dengan posisinya ini, ia dapat menjadi pemersatu bagi masyarakatnya yang sempat terbelah pada saat dilaksanakannya kompetisi pemilihan presiden. Peran ini sering kali terlihat pada pidato pertama seorang presiden (inaugural address) seketika setelah yang bersangkutan diambil sumpah/janjinya sebagai presiden, sebagaimana dilakukan oleh Joe Biden pada 20 Januari 2021.

Dalam pidatonya, Biden mengatakan sudah cukup perselisihan, persaingan, dan pertarungan di antara kita. Saatnya kita kembali bersama-sama untuk membangun Amerika dan mengatasi wabah Covid 19 (Biden, 2021). Ajakan oleh Biden itu menunjukkan bahwa ia paham benar kedudukannya sudah berbeda dengan sebelum pelantikan. Ia sudah menjadi pemegang kekuasaan presiden. Dengan posisinya sebagai presiden, ia mempunyai kewenangan dan kekuasaan konstitusional sehingga dapat memerintahkan penyelesaian perseteruan di dalam masyarakatnya. Jika Biden baru tahapan pidato, Susilo Bambang Yudhoyono 
telah melakukannya ketika ia dapat memimpin koalisi partai pendukung pemerintah untuk mengabaikan kepentingan partai politik guna mewujudkan salah satu klausula perjanjian damai antara Pemerintah Indonesia dan Gerakan Aceh Merdeka, yaitu disetujuinya UndangUndang Nomor 11 Tahun 2006 tentang Pemerintahan Aceh (Anonim, 2014, 13 Oktober).

Di samping sebagai protector of peace, presiden sebagai an arbiter merupakan salah satu keunggulan dari sistem presidensial, menurut Shugart dan Carey. Yang dimaksudkan dengan an arbiter adalah (Shugart dan Carey, 1992):

It is precisely the distance from congressional alliances which the separation of powers ensures that allows the president to act as a moderator of dispute in order to secure a legislative agreement.

Di samping mempunyai peran yang disebutkan oleh Rossiter, presiden juga dapat berperan sebagai penengah ketika terjadi perbedaan pendapat dalam proses legislasi (chief of legislator). Dengan posisinya yang terpisah dari kekuasaan legislatif, presiden dapat menjadi penengah ketika terjadi perbedaan pandangan di antara para anggota legislatif. Ia dipandang netral karena tidak termasuk dalam proses perancangan maupun pengusulan keputusan legislatif tersebut. 
Dengan posisinya yang netral itu, apa yang dikatakan oleh presiden dapat diterima oleh pihak yang berbeda pendapat dalam proses perancangan keputusan legislatif.

Perannya sebagai chief legislator itu dimungkinkan dalam kaitannya dengan kewenangan Presiden Amerika Serikat, namun dalam konteks Indonesia sangat berbeda. Presiden Indonesia mempunyai kewenangan legislatif, yaitu mengajukan rancangan Undang-undang, membahas bersama DPR dan DPD, serta memberikan persetujuan bersama atas Rancangan Undang-undang hasil pembahasan bersama antara DPR, DPD, dan Presiden. Sebaliknya, Presiden Amerika Serikat tidak mempunyai kewenangan seperti counter part-nya di Indonesia.Jangankan memberikan persetujuan bersama, mengusulkan Rancangan Undang-undang (bill) pun, Presiden Amerika Serikat tidak berwenang. Oleh sebab itu, Presiden Amerika Serikat bisa dipandang netral ketika terjadi persilangan pendapat mengenai sebuah bill di the Congress karena yang bersangkutan tidak ikut serta dalam pengusulan ataupun pembahasannya. Inilah kemudian yang menjadi landasan utama mengapa Presiden Amerika Serikat mempunyai kewenangan pocket veto. 
Walaupun mempunyai kewenangan legislatif, Presiden Indonesia tetap saja dapat memerankan chief of legislator sebagaimana terlihat ketika proses pembahasan Rancangan Undang-Undang tentang Cipta Kerja. Presiden dapat menengahi perbedaan pendapat antar partai dan juga antara pemerintah dan DPR/DPD melalui penegasan untuk menarik kembali beberapa substansi yang telah diusulkan dan dibahas bersama dalam tahap pembicaraan pertama pembahasan Rancangan Undang-undang tersebut. Di antaranya, materi muatan mengenai ketenagakerjaan dan pendidikan. Dengan ditariknya kedua substansi itu, maka proses pembahasan yang sempat terhenti kemudian dapat dilanjutkan kembali hingga pada pembicaraan tahap kedua.

Dimungkinkannya Presiden Indonesia berperan sebagai chief of legislator karena ia tidak secara langsung ikut dalam pembahasan bersama setiap Undangundang. Meskipun, Pasal 20 ayat (2) UUD Negara RI Tahun 1945 dengan jelas menentukan bahwa setiap Rancangan Undang-undang dibutuhkan persetujuan bersama, antara DPR dan Presiden. Akibatnya, presiden bisa terhindar dari realitas perdebatan dan perseteruan dalam pembahasan substansiatau materitertentu. Sebab, presiden selalu diwakili oleh pihak yang ditunjuknya 
melalui surat pengantar/kuasa yang dikeluarkan oleh presiden. Menteri atau kepala lembaga/institusi yang biasanya ditunjuk sebagai pemegang kuasa presiden dalam pembahasan setiap Rancangan Undang-undang.

Lebih lanjut pada tahun 1999, presiden juga pernah “menidurkan" Undang-undang tentang Penanggulangan Keadaan Bahaya (UU PKB) meskipun Rancangan Undang-undangnya telah dibahas dan disetujui bersama DPR. Akibatnya, Undang-undang itu tidak pernah berlaku walaupun sudah disetujui bersama antara presiden dan DPR. Bahkan sampai saat ini, Undangundang Nomor 23 Prp. Tahun 1959 tentang Keadaan Bahaya tetap diberlakukan meskipun Undang-undang ini dinyatakan dicabut melalui UU PKB. Proses tidak memberlakukan UU PKB merupakan keputusan politik yang dapat dicapai melalui lobby yang dilakukan oleh presiden kepada anggota DPR. Pertimbangan utama diterimanya tawaran presiden itu disebabkan kondisi politik dan banyaknya penolakan yang dilakukan oleh masyarakat terhadap UU PKB. Bahkan, sampai jatuhnya korban jiwa.

Penangguhan pemberlakuan UU PKB dan peran Susilo Bambang Yudhoyono dalam menetapkan UndangUndang Nomor 11 Tahun 2006 tentang Pemerintahan Aceh menunjukkan peran presiden sebagai chief of 
legislator dalam konteks Indonesia. Artinya, Presiden Indonesia juga dapat berperan sebagai pemimpin pembentukan Undang-undang meskipun kewenangan yang dimilikinya berbeda dengan kewenangan yang dimiliki oleh Presiden Amerika Serikat.

Peran sebagai arbiter dan chief of legislator di atas dilakukan presiden dalam konteks proses legislasi. Apakah peran itu dapat digunakan dalam konteks lainnya? Tentu saja sangat memungkinkan untuk dilakukan pada konteks lain, termasuk memitigasi dan meminimalisir keterbelahan politik. Hal itu dikarenakan seorang presiden wajib mempunyai kapabilitas sebagai negosiator yang ulung. Kemampuan sebagai negosiator yang baik harus ada dalam diri presiden karena presiden berkewajiban untuk memimpin negaranya ketika berhadapan dengan kepentingan negara lain ataupun organisasi internasional. Hal mana ditentukan dalam Pasal 11 UUD NRI Tahun 1945 yang memberikan kewenangan kepada presiden untuk mewakili dan memimpin Indonesia dalam melaksanakan hubungan luar negeri.

Sebagai negosiator, Presiden Indonesia dapat menyelesaikan keterbelahan di masyarakatnya. Khususnya, berkaitan dengan pertentangan di masyarakat sebagai dampak dari pemilihan presiden. 
Seperti yang terjadi dalam kasus kampret versus cebong yang sampai saat ini masih dapat dilihat jejaknya di lini media sosial maupun pertarungan dalam isu-isu politik terkini. Keterbelahan ini sangat kontra produktif dalam proses pelaksanaan pembangunan. Apalagi dalam masa pandemik yang disebabkan oleh corona virus diseases 2019 ini. Dibutuhkan kesatuan dan persatuan dalam menghadapi pandemik ini agar semua komponen masyarakat dapat terlibat dan berkonstribusi dalam mengatasinya.

Dengan demikian, presiden tidak hanya mempunyai kewenangan konstitusional saja tetapi juga presiden mempunyai banyak peran yang dapat dilakukan guna memimpin bangsa mencapai tujuan dibentuknya negara. Berbagai kewenangan dan peran itu dapat dimanfaatkan oleh presiden untuk mengatasi semua hal. Mulai dari ketebelahan politik sampai dengan mengatasi krisis ekonomi. Oleh karenanya, tidak salah jika kemudian John F. Kennedy mengatakan bahwa presiden merupakan jabatan yang paling berkuasa di dunia sebab presiden dapat melakukan apa pun (Hague dan Harrop, 2004). 


\section{MEDIATOR POLITIK: KEBIJAKAN PRESIDEN DALAM MENGIKIS POLITIK DIAMETRAL}

Berbagai kewenangan dan peran yang dimiliki oleh presiden yang telah diuraikan sebelumnya dapat menjadi peluang bagi Presiden Indonesia dalam melaksanakan tugasnya sebagai pemegang kekuasaan pemerintahan. Kewenangan dan peran itu dapat membantunya dalam mengatasi semua hambatan termasuk situasi politik diametral yang terbentuk pasca pemilihan presiden. Sejak tahun 2004, Indonesia telah menerapkan pola pemilihan langsung presiden. Konsekuensinya, kondisi politik yang diametral terbentuk setelah ditentukan pemenang kompetisi presiden dan wakil presiden. Misalnya pada tahun 2004, pemilihan presiden diikuti oleh lima kontestan, yaitu pasangan Wiranto dan Salahuddin Wahid, pasangan Megawati dan Hasyim Muzadi, pasangan Amin Rais dan Siswono Yudohusodo, pasangan Susilo Bambang Yudhoyono dan Jusuf Kalla, dan pasangan Hamza Haz dan Agum Gumelar. Meskipun sebenarnya ada enam pasangan yang mendaftar ke Komisi Pemilihan Umum (KPU) pada saat itu, namun pasangan Abdurrahman Wahid dan Marwah Daud Ibrahim dinyatakan tidak lolos oleh KPU (Anonim 2004, 27 Juli). Akhirnya, kontestasi ini dimenangkan oleh pasangan Susilo Bambang Yudhoyono dan Jusuf 
Kalla melalui dua putaran pemilihan (Anonim 2004, 27 Juli). Putaran kedua harus dilaksanakan karena tidak ada satu pasangan pun yang mendapatkan suara lebih dari $50 \%$.

Pasangan Susilo Bambang Yudhoyono dan Jusuf Kalla kemudian dilantik menjadi Presiden dan Wakil Presiden Republik Indonesia Periode 2004-2009 pada 20 Oktober 2004 (Anonim 2004, 21 September). Pasangan ini awalnya diusung oleh Partai Demokrat, Partai Bulang Bintang, serta Partai Keadilan dan Persatuan Indonesia meskipun kemudian pada putaran kedua, koalisi partai pengusung bertambah dengan bergabungnya Partai Kebangkitan Bangsa, Partai Keadilan Sejahtera, dan Partai Amanat Nasional (Anonim 2004, 17 September). Jadi, terdapat enam partai yang mengusung pemenang Pemilihan Presiden tahun 2004. Keenam partai ini merupakan partai yang mendukung pemerintahan dengan menguasai 276 dari total 550 kursi di Dewan Perwakilan Rakyat Republik Indonesia (DPR) (Anonim 2020, 13 Juli). Penguasaan kursi oleh koalisi pendukung pasangan Susilo Bambang Yudhoyono dan Jusuf Kalla memang lebih dari setengah jumlah kursi DPR. Harapannya, pemerintah tidak akan mendapat kesulitan berarti ketika mengajukan proposal 
anggaran pembangunan guna mendapatkan persetujuan dari DPR.

Di samping itu, kabinet pemerintahan yang dibentuk oleh Susilo Bambang Yudhoyono dan Jusuf Kalla juga harus mengikutsertakan kader dari partai pengusung atau setidaknya seseorang yang di-endorse oleh partai pengusung. Kenyataannya, kabinet pemerintah pasangan ini juga mengikutsertakan kader dari Partai Golongan Karya walaupun Partai Golongan Karya tidak menjadi partai yang mengusung pasangan Susilo Bambang Yudhoyono dan Jusuf Kalla pada putaran pertama maupun putaran kedua pemilihan Presiden dan Wakil Presiden tahun 2004. Adapun kader Partai Golongan Karya yang sempat diajak masuk dalam Kabinet Indonesia Bersatu adalah Aburizal Bakrie, Mohammad Andi Mattalatta, Fahmi Idris, Rachmat Witoelar, dan Paskah Suzetta.

Selanjutnya pada pemilihan presiden dan wakil presiden tahun 2009, kontestasi ini diikuti oleh tiga pasang calon, yaitu pasangan Megawati dan Prabowo Subianto, pasangan Susilo Bambang Yudhoyono dan Boediono, serta Pasangan Jusuf Kalla dan Wiranto. Kompetisi ini akhirnya dimenangkan oleh pasangan Susilo Bambang Yudhoyono dan Boediono dalam satu putaran saja (Anonim 2020, 9 Januari). 
Dalam mengarungi kontestasi ini, pasangan Susilo Bambang Yudhoyono dan Boediono diusung oleh Partai Demokrat, Partai Kebangkitan Bangsa, Partai Keadilan Sejahtera, Partai Amanat Nasional, dan Partai Persatuan Indonesia yang kemudian diikuti oleh enam belas partai pendukung. Partai pendukung tersebut terdiri atas Partai Damai Sejahtera, Partai Karya Peduli Bangsa, Partai Bintang Reformasi, Partai Peduli Rakyat Indonesia, Partai Demokrasi Pembaharuan, Partai Pekerja dan Pengusaha Indonesia, Partai Republika Nusantara, Partai Nasional Banteng Kemerdekaan, Partai Matahari Bangsa, Partai Pemuda Indonesia, Partai Pelopor, Partai Kasih Demokrasi Indonesia, Partai Indonesia Sejahtera, Partai Perjuangan Indonesia Baru, Partai Persatuan Nahdlatul Ummat Indonesia, serta Partai Penegak Demokrasi Indonesia. Artinya, terdapat 21 partai yang akan terlibat dalam mendukung pemerintahan Pasangan Susilo Bambang Yudhoyono dan Boediono. Dengan besarnya koalisi pendukung pemerintahan, itu menjadikan mudah juga menguasai kursi di parlemen dan memang begitulah kenyataannya. Koalisi ini menguasai 314 dari total 560 kursi di DPR (Anonim 2020, 13 Juli). Sekali lagi, pemenang pemilihan presiden dan wakil presiden didukung oleh mayoritas kursi di parlemen. Tidak hanya penguasaan kursi di 
parlemen, sejarah pun berulang di mana Partai Golongan Karya yang tidak menjadi partai pengusung maupun partai pendukung Pasangan Susilo Bambang Yudhoyono dan Boediono juga tetap diikutsertakan dalam Kabinet Indonesia Bersatu II. Kader Partai Golongan Karya yang masuk dalam Kabinet Indonesia Bersatu II, yaitu Agung Laksono, Fadel Muhammad, dan Sharif Cicip Sutarjo.

Di Pemilihan Presiden 2014, Partai Golongan Karya menjadi salah satu partai pengusung pasangan Prabowo Subianto dan M. Hatta Rajasa. Selain Partai Golongan Karya, partai yang menjadi pengusung pasangan calon ini adalah Partai Gerakan Indonesia Raya, Partai Persatuan Pembangunan, Partai Amanat Nasional, Partai Keadilan Sejahtera, dan Partai Partai Bulan Bintang. Di samping partai pengusung, masih terdapat Partai Demokrat sebagai satu-satunya partai pendukung kandidat ini dalam mengikuti kompetesi Pemilihan Presiden 2014. Keseluruhan gabungan partai ini menamakan koalisinya dengan Koalisi Merah Putih. Selain Pasang Prabowo Subianto dan M. Hatta Rajasa, pemilihan presiden di tahun ini juga diikuti satu pasangan lainnya, yaitu pasangan Joko Widodo dan Jusuf Kalla. Kedua pasangan ini kemudian berlomba untuk menduduki jabatan presiden dan wakil presiden periode tahun 2014 sampai dengan 2019. Pada garis 
finish perlombaan ini, akhirnya dimenangkan oleh pasangan Joko Widodo dan Jusuf Kalla yang diusung Koalisi Indonesia Hebat (Anonim 2020, 9 Januari).

Koalisi Indonesia Hebat hanya menguasai 207 dari 560 kursi di DPR (Anonim 2020, 13 Juli). Konsekuensinya, presiden periode ini hanya didukung oleh minoritas di parlemen. Potensi akan terjadinya dead lock sangat besar, seperti yang disinyalir oleh Juan Jose Linz sehingga presiden kemudian melakukan berbagai upaya untuk tetap mendapatkan dukung mayoritas di parlemen. Salah satu upaya yang dilakukan adalah menambah keanggotaan Koalisi Indonesia Hebat dengan menggandeng Partai Golongan Karya, Partai Persatuan Pembangunan, dan Partai Amanat Nasional ke dalam Kabinet Indonesia Kerja. Bergabungnya ketiga partai ini menyebabkan presiden kembali meraih dukungan mayoritas di parlemen dengan total 386 kursi yang dikuasai oleh Kabinet Indonesia Kerja.

Terakhir, pada Pemilihan Presiden dan Wakil Presiden 2019 juga seturut dengan Pemilihan Presiden 2014 yang hanya diikuti oleh dua pasangan kandidat presiden dan wakil presiden. Peserta kompetisi ini meliputi Koalisi Indonesia Maju yang terdiri dari Partai Demokrasi Indonesia Perjuangan, Partai Golongan Karya, Partai Kebangkitan Bangsa, Partai Nasional 
Demokrat, Partai Persatuan Pembangunan, Partai Hati Nurani Rakyat, Partai Keadilan dan Persatuan Indonesia, Partai Bulan Bintang, Partai Solidaritas Indonesia, Partai Persatuan Indonesia, serta Partai Nanggroe Aceh dengan mengusung Pasangan Joko Widodo dan Ma'ruf Amin. Sedangkan lawannya datang dari Koalisi Adil Makmur yang dipimpin oleh Partai Gerakan Indonesia Raya dan beranggotakan Partai Demokrat, Partai Amanat Nasional, Partai Keadilan Sejahtera, Partai Beringin Berkarya, Partai Islam Damai Aman, dan Partai Aceh dengan mengusung Pasangan Prabowo Subianto dan Sandiaga Salahuddin Uno. Kompetisi ini dimenangkan oleh Pasangan Joko Widodo dan Ma'ruf Amin (Anonim 2020, 9 Januari).

Dengan berbekal dukungan mayoritas kursi parlemen pada periode sebelumnya, Koalisi Indonesia Hebat tetap dapat mempertahankannya di periode keanggotaan parlemen berikutnya dengan menguasai 349 dari total 575 kursi (Anonim 2020, 13 Juli). Belum lagi dengan keberhasilan mengajak Partai Gerakan Indonesia Raya masuk ke dalam Kabinet Indonesia Maju yang mengakibatkan penguasaan Koalisi Indonesia Hebat bertambah besar di DPR dengan menguasai 427 kursi (Anonim 2020, 13 Juli). 
Narasi hasil pemilihan presiden, koalisi partai pengusung, dan penguasaan parlemen di atas menunjukkan peran Presiden Indonesia sebagai chief of legislative dan arbiter yang handal. Kehandalannya itu dibuktikan dengan tetap mempertahankan mayoritas dukungan di parlemen terhadap pemerintahan yang dipimpinnya. Keberhasilan ini dapat diraih oleh presiden dikarenakan ia merupakan pemimpin kabinet dan yang secara konstitusional mempunyai kewenangan untuk mengangkat dan memberhentikan para pembantunya, khusus para menteri. Walaupun, tidak ada satu ketentuan apa pun dalam UUD NRI Tahun 1945 yang mewajibkan presiden untuk membentuk koalisi pendukungnya di parlemen.

Dengan menggunakan kewenangannya itu, presiden memerankan dirinya sebagai chief of legislative dan arbiter guna menghindari ataupun meminimalisir terjadinya dead lock dalam hubungannya dengan DPR. Hal ini menunjukkan bahwa presiden dalam sistem presidensial dapat memerankan dirinya sebagai pihak utama yang dapat meminimalisir atau memitigasi terbentuknya presiden minoritas. Jadi, pendapat Linz yang mengatakan bahwa defect yang terdapat dalam sistem presidensial tidak dapat dihindari dengan mekanisme demokratis apa pun, terbukti 
keliru. Kekeliruan itu disebabkan karena Linz tidak mempertimbangkan kemampuan serta peran dari seorang presiden sebagai daya tarik untuk mengatasi atau menghindari dead lock. Dead lock itu bisa disiasati dengan menarik sebesar mungkin dukungan dari partai-partai di parlemen untuk mendukung presiden yang berkuasa. Metode yang digunakan pun sangat sederhana dengan menawarkan posisi bagi para kader partai untuk masuk dalam kabinet pemerintahan. Cara ini mirip dengan strategi yang digunakan dalam sistem parlementer guna mengumpulkan sebanyak mungkin dukungan di parlemen agar setiap proposal kebijakan yang diusulkan pemerintah dapat diterima oleh parlemen. Di samping untuk menghindari diberikannya mosi tidak percaya kepada kabinet pemerintahan.

Daya pikat untuk diikutsertakan dalam kabinet pemerintahan sangat manjur untuk menarik dukungan dari partai-partai politik. Bahkan, dapat menarik partai politik yang menjadi rival utama dalam pemilihan umum atau pemilihan presiden agar masuk dalam koalisi pendukung pemerintahan. Daya tarik inilah yang dimanfaatkan oleh seorang presiden dalam mengatasi dendam kesumat di antara para pemenang pemilihan umum dengan pihak yang kalah. 
Selain itu, ilustrasi hasil pemilihan Presiden Indonesia di atas juga dapat ditunjukkan bahwa terdapat kebiasaan atau perilaku yang berasal dari sistem parlementer dan diterapkan dalam kehidupan politik di Indonesia. Meskipun demikian, fungsi koalisi partai politik itu tidak dimaksudkan untuk mempertahankan eksistensi presiden. Melainkan, koalisi partai politik ini diperlukan untuk memperlancar proses interaksi antara presiden dan parlemen, baik itu dalam persetujuan anggaran pembangunan, program kerja, pengawasan, maupun sampai pada pembentukan ataupun penundaan pelaksanaan Undang-undang.

Secara ringkas, pengalaman Indonesia dan Amerika Serikat dapat menunjukkan bahwa hipotesis yang dibangun oleh Linz dapat diatasi ataupun diminimalisir dengan cara-cara yang beradab dan demokratis guna terhindar dari dead lock dalam hubungan eksekutif dan legislatif meski tidak semua anggota parlemen menjadi bagian dari koalisi pendukung pemerintah. Jadi, tetap ada partai atau anggota parlemen yang berperan sebagai opposant dari pemerintah. Jika seluruhnya menjadi pendukung pemerintah, maka gelaja otoriter dan terabaikannya checks and balances pasti terjadi.

Pendekatan yang dilakukan oleh presiden itu dengan memanfaatkan perannya sebagai arbiter dan chief of 
legislator. Kedua peran ini terbukti cukup efektif untuk meminimalisir ataupun menghindari gejala dead lock dalam hubungan presiden dan parlemen. Peran yang sama juga dapat dimanfaatkan guna menyelesaikan politik diametral dalam masyarakat pasca pelaksanaan pemilihan umum melalui pemanfaatan kewenangannya sebagai presiden dan pemimpin bangsa.

\section{KESIMPULAN}

Dengan membawa defect dalam karakternya dan melahirkan tradisi keterpisahan, sistem presidensial tetap mempunyai jalan keluar dari kemungkinan terjadinya dead lock dalam penerapannya. Solusi atas permasalahan itu dapat dilakukan oleh presiden dengan berperan sebagai chief of legislative dan arbiter. Peran itu juga dapat ditemukan pada pengalaman di Indonesia karena sistem pemerintahan yang diberlakukan di Indonesia pasca perubahan UUD 1945 merupakan sistem presidensial.

Pengalaman Presiden Indonesia dan Amerika Serikat telah menunjukkan keberhasilan untuk menghindarkan sistem presidensial menuju dead lock, sebagaimana disinyalir oleh Juan Jose Linz. Oleh karenanya, seorang presiden harus mempunyai karakter yang dapat 
memainkan peran sebagai mediator atau dalam bahasa sehari-hari presiden sebagai negarawan. Tanpa itu, sistem presidensial akan menjadi mimpi yang buruk bagi kehidupan politik di negara yang menerapkannya. Jadi, tidak salah jika kemudian disimpulkan juga bahwa the center of presidential government terletak pada jabatan presiden. Jabatan ini dapat menjadi solusi atas berbagai kekurangan yang ada atau terkandung dalam sistem presidensial walaupun tetap perlu dilakukan pengaturan dan pengawasan yang baik terhadap kekuasaan presiden. Sebab, inilah satu-satunya jabatan negara yang diberikan kepada perseorangan. Dengan kodratnya sebagai manusia, maka pemegang jabatan presiden sudah pasti mempunyai kekurangankekurangan dalam melaksanakan kewenangannya. Guna menghindari hal itu, pengawasan yang dilakukan dan penyeimbangan dari pemegang kekuasaan negara lainnya tetap harus dilakukan dengan baik dan benar agar supaya jabatan presiden tidak disalahgunakan. 


\section{REFERENSI}

\section{Buku}

Asshiddiqie, Jimly. (2007). Pokok-pokok Hukum Tata Negara Indonesia Pasca Reformasi. Jakarta: Buana Ilmu Populer.

Ball, Allan R. (1988). Modern Politics and Government, Fourth Edition. London: Macmillan Education Ltd.

Blondel, Jean. (2015). The Presidential Republic. New York: Palgrave Macmillan.

Budiardjo, Miriam. (2008). Dasar-Dasar Ilmu Politik, Edisi Revisi. Jakarta: PT. Gramedia Pustaka Utama.

Cheibub, Jose Antonio. (2007). Presidentialism, Parliamentarism, and Democracy. United Kingdom: Cambridge University Press.

Diantha, I Made Pasek. (1990). Tiga Tipe Pokok Sistem Pemerintahan dalam Demokrasi Modern. Bandung: CV. Abardin.

D. Moh. Mahfud M.. (2001). Dasar dan Struktur Ketatanegaraan Indonesia, Edisi Revisi, Cetakan II. Jakarta: PT. Rineka Cipta.

Elgie, Robert (ed.) (2004). Semi-Presidentialism In Europe. Oxford: Oxford University Press. 
Elgie, Robert. (2011). Semi-Presidentialism: Sub-Types and Democratic Performance. Oxford: Oxford University Press.

Feijó, Rui Graça. (2021). Presidents in Semi-Presidential Regimes: Moderating Power in Portugal and TimorLeste. Cham: Palgrave Pivot.

Hague, Rob dan Martin Harrop. (2004). Comparative Government and Politics: An Introduction, 6th Edition. New York: Palgrave MacMillan.

Isra, Saldi. (2019). Sistem Pemerintah Indonesia: Pergulatan Ketatanegaraan Menuju Sistem Pemerintahan Presidensial. Depok: Rajawali Pers.

Kelompok Kerja Forum Rektor Indonesia 2006-2007. Penyempurnaan Amandemen Undang-Undang Dasar 1945. Yogyakarta: Gadjah Mada University Press.

Keman, Hans (Ed). (2002). Comparative Democratic Politics: A Guide to Contemporary Theory and Research. London: Sage Publications Ltd.

Keyes, Ralph. (2011). The Post-Truth Era: Dishonesty and Deception in Contemporary Life. New York: St. Martin's Press. 
Komisi Hukum Nasional Republik Indonesia. (2014). Mohammad Fajrul Falaakh: Konsisten Mengawal Konstitusi. Jakarta: Komisi Hukum Nasional Republik Indonesia.

Lijphart, Arend. (1984). Democracies: Patterns of Majoritarian and Consensus Government in Twentyone Countries. Connecticut: Yale University Press.

Linz, Juan J. dan Arturo Valenzuela (Eds.). (1944). The Failure of Presidential Democracy - Comparative Perspectives. Baltimore: The Johns Hopkins University Press.

Mahler, Gregory S. (2000). Comparative Politics: An Institutional and Cross-National Approach, Third Edition. New Jersey: Prentice-Hall Inc.

Majelis Permusyawaratan Rakyat Republik Indonesia. (2017). Panduan Pemasyarakatan Undang-Undang Dasar Negara Republik Indonesia Tahun 1945 dan Ketetapan Majelis Permusyawaratan Rakyat Republik Indonesia, Cetakan Keenam Belas. Jakarta: Sekretariat Jenderal MPR RI.

Manan, Bagir. (1999). Lembaga Kepresidenan. Yogyakarta: Penerbit Gama Media. 
McConville, Mike dan Wing Hong Chui. (Eds.). (2007). Research Methods for Law. The Great Britannia: the Edinburg University Press.

Pamudji. (1994). Perbandingan Pemerintahan. Jakarta: Bumi Aksara.

Polsby, Nelson. (2011). Congress, National Security, and the Rise of Presidential Branch. Dalam James P. Pfiffner, The Modern Presidency, 6 Edition, (hlm. 4). Boston: Wardworth-Cengage Learning.

Przeworski, Tamar Adam Asadurian, dan Anjali Thomas Bohlken. (2012). "The Origins of Parliamentary Responsibility.” Dalam Tom Ginsburg (ed.), Comparative Constitutional Design (hlm. 101-137). New York: Cambridge University Press.

Rossiter, Clinton. (1963). The American Presidency, Revised Edition. New York: Mentor Books.

Sartori, Giovanni. (1994). Comparative Constitutional Engineering: An Inquiry into Structures, Incentives, and Outcomes. London: MacMillan Press Ltd.

Shugart, Matthew Soberg dan John M. Carey. (1992). Presidents and Assemblies: Constitutional Design and Electoral Dynamics. United Kingdom: Cambridge University Press. 
Seomantri, Sri. (1992). Bunga Rampai Hukum Tata Negara Indonesia. Bandung: Alumni.

Soekanto, Surjono. (1986). Pengantar Penelitian Hukum. Jakarta: UI Press.

Strong, C.F. (1963). A History of the Modern Political Constitutions (First American Edition). New York: G.P. Putnam's Sons.

Suny, Ismail. (1987). Mekanisme Demokrasi Pancasila. Jakarta: Aksara Baru.

Verney, Douglas V. (1959). The Analysis of Political System. The Great Britannia: The Free Press.

\section{Peraturan Perundang-undangan}

Undang Undang Dasar Negara Republik Indonesia Tahun 1945 .

The United States Constitution.

\section{Jurnal/Artikel}

Calabresi, Steven G. dan Kevin H. Rhodes (1992). The Structural Constitution: Unitary Executive, Plural Judiciary. Harvard Law Review, 105 (6), 1153-1216. 
Duverger, Maurice. (1980). A New Political System Model: Semi-Presidential Government. European Journal of Political Research, 8, 165-187.

Falaakh, M. Fajrul. (2003). Presidensi dan Proses Legislasi Pasca-Revisi Konstitusi (Parlementarisme Lewat Pintu Belakang?). Yogyakarta: Seminar Nasional Meluruskan Jalan Reformasi, Universitas Gadjah Mada, 25-27 September 2003.

Mainwaring, Scott dan Matthew Søberg Shugart. (1997). Juan Linz, Presidentialism, and Democracy: A Critical Appraisal. Comparative Politics, 29 (4), 449-471.

Kaminsky, Elijah Ben-Zion. (1997). On the Comparison of Presidential and Parliamentary Governments. Presidential Studies Quarterly, 2 (2), 221-228.

Lay, Cornelis. (2006). State Auxiliary Agencies. Jantera: Jurnal Hukum, 12 (III), 5-21.

Linz, Juan Jose. (1990). The Perils of Presidentialism. Journal of Democracy, 1 (1), 51-69.

Nakaguma, Marcos Yamada. (2005). Choosing the Form of Government: Theory and Evidence from Brazil. The Economics Journal, 125 (589), 1986-2023.

Puig, Gonzalo Villalta. (2002). Parliamentary versus Presidential Government. Australian Quarterly, 74 (5), 9-11, 40. 
Roper, Steven D. (2002). Are All Semi-Presidential Regimes the Same? A Comparison of Premier-Presidential Regimes. Comparative Politics, 34 (3), 253-272.

Shugart, Matthew Søberg. (2005). Semi-Presidential Systems: Dual Executive and Mixed Authority Patterns. France Politics, 3, 323-351.

Skach, Cindy. (2007). The "Newest" Separation of Powers: Semipresidentialism. International Journal of Constitutional Law, 5(1), 93-121.

\section{Internet}

Anonim. (2004, 27 Juli). Yudhoyono dan Megawati Lolos Pilpres Putaran Dua. Liputan 6. Diakses dari www. liputan6.com.

Anonim. (2004, 17 September). SBY-JK Rapat Koordinasi dengan Partai-partai Pendukung. Detik. Diakses dari www.detik.com.

Anonim (2004, 21 September). SBY-Kalla Umumkan Kabinet Saat Dilantik 20 Oktober. Detik. Diakses dari www.detik.com.

Anonim. (2014, 13 Oktober). Konflik Aceh Selesai di Tangan SBY. Detik. Diakses dari www.detik.com. 
Anonim. (2020, 9 Januari). Hasil Perhitungan Suara Sah Pemilu Presiden dan Wakil Presiden Menurut Provinsi Tahun 2004, 2009, 2014, 2019. Badan Pusat Statistik. Diakses dari www.bps.go.id.

Anonim. (2020, 13 Juli). Hasil Penghitungan Suara Sah Partai Politik Peserta Pemilu Legislatif Tahun 19552019. Badan Pusat Statistik. Diakses dari www.bps. go.id.

Amadeo, K. (2020, 28 Februari). Government Shutdowns in 1995, 2013, 2018, and 2019 Explained. The Balance. Diakses dari www.thebalance.com.

Biden, Jr. Joseph R. (2021, 20 Januari). Inaugural Address by President Jr. Joseph R. Biden. The White House. Diakses dari www.whitehouse.gov.

McCann, E. (2013, 1 Oktober). What Services are Affected When The US Government Shuts Down. The Guardian. Diakses dari www.theguardian.com.

Puspasari, Rahayu. (2020, 10 Mei). Perkembangan Ekonomi dan Refocusing Anggaran untuk Penanganan Covid-19 di Indonesia. Kementerian Keuangan Republik Indonesia. Diakses dari www.kemenkeu.go.id.

Sholikah, Binti dan Muhammad Hiru. (2021, 28 Januari). Pembangunan Rumah Sakit Lapangan Covid-19 Selesai. Republika. Diakses dari www.republika.co.id. 
Weisman, J. and Peters. J.W. (2013, September 30). Government Shuts Down in Budget Impasse. The New York Times. Diakses dari www.nytimes.com. 